К. М. Ковальов, заступник директора,

Державний науково-дослідний експертно-

криміналістичний иентр МВС України, м. Київ

ORCID: https://orcid.org/0000-0003-1964-9283

\title{
ГЕНЕЗИС ДОКУМЕНТА ЯК ЗАСАДИ КРИМІНАЛІСТИЧНОГО ДОКУМЕНТОЗНАВСТВА ТА ОБ'ЄКТА ДОСЛІДЖЕННЯ В ТЕХНІЧНІЙ ЕКСПЕРТИЗІ ДАВНОСТІ ДОКУМЕНТА
}

\begin{abstract}
Mema статті полягає у визначенні документа як засади криміналістичного документознавства та об’єкта дослідження в технічній експертизі давності документа крізь призму його становлення та розвитку, що надасть можливість удосконалити наявні та сформувати нові науково-методичні підходи як підгрунтя для створення нової експертної спеціальності - дослідження давності виготовлення документа. Методологія. Достовірність отриманих результатів і висновків забезпечено використанням комплексу загальнонаукових методів дослідження, серед них аналіз, синтез, індукція, аналогія, дедукція тощо. Крім того, для практичної реалізації використано такі форми знання, як поняття, закони, гіпотези, теорії, що дають змогу надалі застосовувати їх, отримуючи наукову апробацію. Наукова новизна. Уточнено поняття документа у криміналістичній площині. Надано авторське поняття документа як об'єкта дослідження в галузі криміналістичного документознавства, зокрема технічної експертизи документів, з метою визначення давності його виготовлення. Сформовано підгрунтя для створення нової експертної спеціальності - дослідження давності виготовлення документа. Висновки. Проаналізовано етапи створення та розвитку документа як матеріального носія інформації у просторі і часі, генезис загального та спеціального поняття документа, зокрема й у криміналістичному розумінні. Визначено критерії формування поняття документа як об'єкта дослідження в галузі криміналістичного документознавства і технічної експертизи документів. Надано пропозиції з удосконалення наявних і формування нових науково-методичних підходів, що становлять підгрунтя для створення нової експертної спеціальності - дослідження давності виготовлення документа.
\end{abstract}

Ключові слова: документ; генезис поняття документа; криміналістичне документознавство; технічна експертиза документів; визначення давності виготовлення документа.

\section{Вступ}

Документ, набравши юридичної ваги в суспільних відносинах, став предметом прискіпливої уваги як фахівців у різних сферах життєдіяльності людини й суспільства, так і підроблювачів, поступово перетворюючись на один з атрибутів держави та суспільних відносин, доказів у судочинстві та об’єкт дослідження. 3 набуттям такого особливого статусу актуалізувалися наукові дослідження формування поняття документа, визначення його властивостей, цілей тощо.

Історію виникнення та еволюцію тлумачення терміна «документ» вивчали, зокрема, Х. Арнтц, Д. І. Блюменау, Г. Г. Воробйов, О. П. Коршунов, Н. М. Кушнаренко, К. Г. Мітяєв, А. В. Соколов, Ю. М. Столяров, О. І. Михайлов, Ш. Р. Ранганатан, Д. І. Рудельсон, Д. Ю. Тегагов, Г. Г. Фірсов, Г. М. Швецова-Водка, В. І. Шюрмайер. Документ як предмет криміналістичного дослідження розглядали Т. В. Варфоломеєва, О. П. Вершинін, В. Р. Гаррісон, Н. Джо, Е. Девід, І. В. Калініна, В. В. Коваленко, Т. Е. Кукарнікова, В. К. Лисиченко, Д. Я. Мирський, А. Ш. Осборн, М. В. Салтевський, М. Я. Сегай, В. М. Тихоненко, О. Г. Філіппов, М. А. Хедрік, А. Р. Хубер, Г. М. Шаповалова, В. Ю. Шепітько.
Сьогодні науковці і практики висвітлюють питання, пов'язані, серед іншого, з теоретико-методологічними засадами експертизи цінності документів в електронній формі, доказовою цінністю електронного документа, зважаючи на те, що на сучасному етапі розвитку суспільства та суспільних відносин значущість документа, вигляд якого з традиційно звиклого паперового (матеріального) послідовно трансформується у найбільш сучасний електронний, неухильно зростає (Cherniatynska, 2017; Golovanov, Kulikova, Shmalij, Tychinin, \& Hlebnikov, 2018); криміналістичною класифікацією документів (Gavrilin, 2018); криміналістичним дослідженням документів зі зміненим первинним змістом (Yudina, 2018); інструментами вимірювання для судової експертизи документів (van Erp, Vuurpijt, Franke, \& Schomaker, 2018); об'єктами експертизи встановлення давності документа (Stratonov, 2020); класифікаційною схемою як відображенням соціально-комунікаційної природи феномена документа (Komova, 2019); оперативно-розшуковим документуванням (Sakovskyi, 2020); судовою автентифікацією документів (Garain, \& Halder, 2020); аналізом і розпізнаванням історичних документів (Lombardi, \& 
Marinai, 2020); експертизою судових документів у XXI ст. (Kelly, \& Angel (Eds.), 2020); розширенням значення терміна «документ» як чинника можливого переосмислення об’єктів (Lazarev, 2020); загальнотеоретичним підходом до дослідження підроблених текстів і документів у криміналістичній експертизі (Antoniuk, Zakharkiv, \& Franchuk, 2020); генезисом криміналістичного дослідження документів як галузі криміналістичної техніки (Sezonov, 2020).

Проте наразі бракує грунтовних досліджень генезису документа як засади криміналістичного документознавства та об’єкта дослідження в технічній експертизі давності документа, аспектів формування та розвитку поняття документа, зумовлюючи необхідність його уточнення (формулювання нового) в криміналістичній площині, а також об’єкта дослідження в галузі криміналістичного документознавства. Окреслене визначає актуальність обраної тематики і конкретизує подальші напрями наших розвідок.

\section{Мета й завдання статті}

Мета статті полягає у визначенні документа як засади криміналістичного документознавства та об'єкта дослідження в технічній експертизі давності документа крізь призму його становлення та розвитку, що надасть можливість удосконалити наявні та сформувати нові науково-методичні підходи як підгрунтя для створення нової експертної спеціальності - дослідження давності виготовлення документа.

Для досягнення цієї мети потрібно виконати такі завдання:

проаналізувати історичні аспекти розвитку документа як засади криміналістичного документознавства та об’єкта дослідження в технічній експертизі давності документа;

уточнити поняття документа у криміналістичній площині;

сформувати поняття документа як засади криміналістичного документознавства та об'єкта дослідження в технічній експертизі давності документа;

надати пропозиції з удосконалення наявних i формування нових науково-методичних підходів як підгрунтя для створення нової експертної спеціальності - дослідження давності виготовлення документа.

\section{Виклад основного матеріалу}

Генезис документа нерозривно пов'язаний iз розвитком мовлення та писемності. Первинну інформацію про навколишній світ людина сприймала через органи чуттів (органи зору, слуху, дотику). Передавалась інформація від людини до людини завдяки мові спочатку в усній, а згодом ще й у письмовій формі.

Мова - це особлива система, у якій за допомогою знаків (букв, цифр, умовних позначок та ін.) i граматичних правил конструюються смислові лексичні одиниці (слова, словосполучення, речення). Будь-яке речення, складене на основі певної мови, може фіксуватися різними символами і засобами.

За роки свого існування людство розробило чимало мов, які поділяють на природні (історично виниклі в процесі розвитку суспільства - українська, англійська й ін.) і штучні (спеціально розроблені для фіксації чи передавання відомостей - азбука Морзе, мови програмування тощо).

Найбільший винахід суспільства для передавання мовленнєвої інформації у часі й на відстані - створення письма та писемності (Biriukov, Kovalenko, Biriukova, \& Kovalov, 2007, s. 34-35).

Письмо являє собою знакову систему фіксації мовлення, що дає змогу символами передати мовленнєву інформацію на відстані та зберігати iї впродовж тривалого часу. Писемність - сукупність письмових засобів фіксації та передавання інформації, що охоплює графіку, алфавіт і орфографію будь-якої мови чи групи мов, об’єднаних єдиною системою письма або одним алфавітом (Kushnarenko, 2006, s. 78).

Зародженням писемності вважають перші наскельні малюнки (4 млн рр. до н. е.), за допомогою яких люди намагалися передати якусь важливу інформацію. Основою для цієї писемності була скеля (камінь), а фарбовою речовиною - зола чи інший матеріал.

Піктографічне письмо виникає майже 3200 p. до н. е., коли шумери в Месопотамії для збереження та передавання невеликої за обсягом інформації почали використовувати серії малюнків. 3 часом знаки дедалі менше були схожі на малюнки, унаслідок чого з'явилися умовні знаки. Месопотамські писці писали на глиняних табличках із сирої глини, оскільки в тих місцях їі було вдосталь. Знаки наносилися стилусом - пір'ям, виготовленим 3 очерету з трикутним кінцем, тому цей вид письма дістав назву клинопис. Вавилоняни започаткували розмноження документів у вигляді тисяч клинописних табличок (Palekha, \& Lemish, 2011, s. 48; Sánchez, Romero, Toselli, Villegas, \& Vidal, 2019; Bogacz, \& Mara, 2020; Dencker, Klinkisch, Maul, \& Ommer, 2020).

Наступний етап - утворення 3100 р. до н. е. у Стародавньому Єгипті ієрогліфічної писемності (проіснувала впродовж трьох тисячоліть), за якої знак (символ) позначав не тільки конкретний предмет, а й звук. Інформацію на папірус писці наносили за допомогою чорнила та пера з очерету. 
Пізніше такий вид писемності набув поширення у Китаї, Японії та Кореї. За допомогою ієрогліфів можна відобразити будь-яку думку або інформацію.

У II ст. до н. е. з'являється конкурент папірусу - пергамент (Mysak, 2016, s. 241-242). Цей матеріал для письма з недубленої шкіри тварин почали виробляти в Малій Азії, у місті Пергамі (зараз Бергама, Туреччина).

Папір винайшли в Китаї приблизно в 100 р. н. е. завдяки зусиллям стародавнього винахідника Цай Луня. До цього на Сході найпоширенішим матеріалом для виготовлення документів був шовк. По шовку писали чорною або червоною тушшю пензликами різної величини. Збільшення виробництва паперу зумовило поступовий процес заміни шовку на дешевший матеріал - папір, який став основним матеріалом для виготовлення документів (Otlet, 1934, p. 47; Kuleshov, 2012).

Технологію виготовлення паперу китайці дуже довго тримали в секреті, тому до сусідів він потрапив як носій священних текстів буддизму. До Кореї - у V ст., Японії - на початку VII ст., у $\mathrm{V}$ ст. з папером познайомилися країни Південно-Східної Азії. У VII ст. папір почали використовувати в Індії, VIII ст. - у Західній Азії. До Африки цей матеріал «дійшов» у X ст., у XII - папір підкорив Європу, а в XVI - його вже знали в Америці (Mysak, 2016, s. 243).

В Україні перше виробництво придатного до друку паперу організував Єлисей Плетенецький у місті Радомишлі наприкінці першої чверті XVIII ст. для потреб друкарні Києво-Печерської Лаври (Kushnarenko, 2006, s. 51).

Розвиток та удосконалення виробництва паперу сприяло розвитку техніки, що використовувалася для нанесення текстів на папір. Так, зі звичайного напису та переписування за допомогою чорнила та пір'їв, дякуючи винаходу Йоганна Гутенберга, який у середині XV ст. створив друкарський верстат, народилось друкарство.

I такий поступ був можливий завдяки алфавіту, за яким тисячолітня історія.

Перший алфавіт, що став основою для писемності багатьох народів і започаткував розвиток значної кількості сучасних алфавітів, створили фінікійці у II тисячолітті до н. е. Складався він не з піктограм, а з 22 знаків. Кожен знак відповідав окремому приголосному звуку й був літерою. На письмі голосні пропускалися.

Після того як фінікійську писемність перейняли греки, до неї додалися голосні звуки. Для їх позначення використовувалися фінікійські знаки, які не мали фонетичних еквівалентів у грецькій мові. Завдяки грецькому удосконаленню фінікійського алфавіту перша буква «алеф», яка означала «буйвол», трансформувалася в «альфу» та поклала початок походженню слова «алфавіт». У 780-х рр. н. е. в Європі виникла перша стандартизована система письма - каролінговий мінускул, у якому з'явилися великі та малі літери.

Тобто створення і подальше вдосконалення стандартизованої системи письма - алфавіту й технічна революція, втіленням якої став винахід у вигляді друкарського верстата, сприяло великому поширенню друкованих документів, які стали невід’ємною частиною міжлюдських відносин, формування порядку та правил існування суспільства й держави, а також становленню міждержавних відносин.

Документ є базовим складником поняттєво-термінологічної системи як загального, так і криміналістичного документознавства.

Документознавство як галузь науки орієнтоване на вивчення закономірностей створення й розвитку документів, чинників їх виникнення, розроблення класифікації, дослідження змісту та визначення функційних зобов'язань і ролі документа в житті суспільства, держави, особи (Bezdrabko, 2017, s. 5).

3 огляду на специфіку створення документа, особливості його використання та зберігання людством у різноманітних сферах життєдіяльності, суспільних відносин у кожній із цих галузей закладається своє розуміння документа та його значення, формується окреме поняття документа, ставлення до нього. Фахівці у сфері дослідження історії до документів відносять лише первинні документи, у яких інформація закріплена за допомогою способів, що існували на той період часу; посадові особи державних органів управління в документах убачають нормативне закріплення певних дій, засвідчення особи та правочинів; правознавці вважають насамперед джерелом доказів.

За багаторічну практику управління державою, урегулювання суспільних відносин тощо людство напрацювало певні вимоги до документа, які знайшли своє відображення у державних стандартах, положеннях, інструкціях, статутах, наказах і правилах, що регламентують діяльність державних і громадських установ, організацій і закладів. Згідно з цими вимогами документ має виходити від певної фізичної або юридичної особи, а викладені в ньому відомості про події чи факти повинні бути реальними, такими, що відбувалися у конкретному місті та в певний період часу, що відображають бажання чи волю особи. Для забезпечення цього були створені форми складання документа відповідно до його завдань, до яких віднесли мову складання, структуру, зміст, спосіб оформлення, порядок реєстрації тощо. 
Документом (від лат. dokumentum, що походить від doceо - учу, доводжу (Melnychuk (Hol. red.), 1985, s. 105; Pustovit, Skopnenko, Siuta, \& Tsymbaliuk (Uklad.), 2000, s. 386) у Стародавньому Римі вважали все, що могло слугувати взірцем, посвідченням, доказом. При цьому в давньоримському праві слово «dokumentum» було синонімом до термінів «instrumentum», «scriptura», «charta», кожен з яких означав письмовий акт, що має доказову силу або юридичну вагу (Tsarova, 2017, s. 27).

3 цього, власне, випливає, що сформовано (закладено) кілька напрямів використання документа в житті людини, серед яких загальновживаний, науковий, суспільно-державний, юридичний і криміналістичний.

У контексті окресленої проблематики найбільший інтерес становлять суспільно-державний, юридичний і криміналістичний. Що стосується останнього напряму, то постала потреба у визначенні поняття документа не лише в галузі знань - криміналістиці, а й в окремих їі складових, насамперед у криміналістичному документознавстві. Адже понятійний апарат цілої галузі не повною мірою відбиває сутність того, що досліджують і вивчають у межах складових криміналістичного документознавства, а саме технічної експертизи документів, зокрема й визначення давності виготовлення документа.

Отже, зважаючи на особливості життєдіяльності та суспільних відносин, смисловий аспект поняття документа, що вирізняється широким та вузьким змістом, має певне вираження та значення. При цьому кожна зі згаданих галузей життєдіяльності та суспільних відносин людини не може існувати окремо від іншої, зумовлюючи свій вплив на формування документів і функціонування документообігу. Унаслідок дефініції поняття документа в суспільних і державних відносинах, юриспруденції, зокрема й криміналістиці, розрізняються.

Питання визначення поняття документа становили інтерес не одного покоління науковців i практиків.

Так, Словарь русского языка, составленный вторымъ отдъленіемъ Академіи наукъ (1895р.), документом визнавав «письменный актъ, служащій доказательствомъ или свидътельствомъ чего-либо; дъловая бумага, относящаяся къ канцелярскому производству» (Zhizhilenko, 1900, s. 539).

Найбільший внесок у формування емпіричного поняття документа зробив Поль Отле, який у праці «Руководство к администрированию» (1924 р.) надав таке одне 3 перших визначень: «Документ - кристаллизованная мысль. Это материальное выражение какого-либо факта или какой-либо идеи; это то материальное свидетельство, на которое опираются при утверждении факта или идеи. Слово «документ» имеет тот же корень, что доктрина и догма (docere, doctum); в обычном словоупотреблении это всякий след идеи на бумаге, это - сама бумага» (Otle, 1924, s. 4). Це «матеріалізована пам'ять людства, яка день за днем реєструє факти, ідеї, дії, почуття, мрії, що відбилися в свідомості людини» (Otlet, 1934, p. 42; Shvetsova-Vodka, 1998, s. 7).

Надалі узагальнений генезис поняття документа знайшов своє відображення у тлумачних словниках: як діловий папір, що посвідчує певний юридичний факт, підтверджує право на що-небудь, служить доказом чого-небудь; усе те, що підтверджує що-небудь; письмове свідоцтво, що офіційно підтверджує особу; письмовий твір, грамота, рисунок і т. ін. як свідчення про щось історичне, важливе (Bilodid (Holova redkol.), 1971, s. 356); спец., форматований паперовий носій даних, що його заповнюють автоматично або вручну (Busel (Uklad. i Holov. red.), 2005, s. 236).

При цьому слід зауважити, що окремі науковці, пропонуючи власні дефініції, грунтувалися винятково на властивостях (Tsarova, 2017, s. 19) документа, до яких належать:

атрибутивність - наявність невід'ємних частин, без яких він існувати не може. Документ як цілісна система складається 3 двох основних додатків - інформаційного і матеріального. Відсутність однієї зі складових перетворює документ на недокумент (на усне мовлення, річ);

функціональність - призначення для передавання інформації у просторі та часі. Документ як поліфункціональний об'єкт виконує безліч загальносистемних і специфічних функцій, зумовлених різноманітними потребами суспільства в інформації, знаннях;

структурність - тісний взаємозв'язок елементів і підсистем, що забезпечує його цілісність і тотожність самому собі, тобто збереження основних властивостей за різних зовнішніх і внутрішніх змін. Типову структуру (однаковий набір елементів для певного виду документів) мають практично всі документи, що функціонують у системі соціальних комунікацій. Типова структура документів різних видів визначається спеціальними стандартами, положеннями, інструкціями тощо. Саме структура забезпечує ефективність використання і довготривалість зберігання документа.

Приклади таких визначень, що їх надали інші дослідники, проаналізувала Г. М. Швецова-Водка, серед них: «документ - матеріальний об'єкт, що містить інформацію в закріпленому вигляді»; «документ - матеріальний об'єкт, що містить закріплену інформацію, спеціально призначений для іiї передачі в просторі та часі і такий, що використовується в суспільній практиці»; «документ 
- матеріальний об’єкт, що містить інформацію в заданому вигляді і спеціально призначений для іiі розповсюдження в просторі та часі»; «документ - матеріальний об'єкт, що містить закріплену інформацію і спеціально призначений для іï передачі та використання»; «документ - це будь-який матеріальний носій, на якому людиною зафіксована (закріплена) соціальна інформація» (ShvetsovaVodka, 1998, s. 8-9).

Загальноправове (нормативно-юридичне) поняття документа витлумачувалося у державних стандартах: «документ - записана інформація, яка може розглядатися як одиниця під час здійснення інформаційної діяльності» (Informatsiia ta dokumentatsiia, 1994, pidp. 4.2.3 - утратив чинність); «матеріальний об'єкт, що містить інформацію, закріплену створеним людиною способом для іiі передавания в часі та просторі» (Vydannia. Osnovni vydy, 1995, pidp. 3.1 - утратив чинність); «документ - інформація, зафіксована на матеріальному носії, основною функцією якого є зберігати та передавати ії в часі та просторі» (Dilovodstvo y arkhivna sprava, 2005, pidp. 3.3).

У законодавстві України про інформацію документ окреслено як «матеріальний носій, що містить інформацію, основними функціями якого $\epsilon$ іiї збереження та передавання у часі та просторі» (Pro informatsiiu: Zakon Ukrainy, 1992, st. 1).

Отже, юридичне тлумачення поняття «документ», слушно наголошує I. В. Царьова, дещо відрізняється від наведених визначень.

Так, в адміністративному праві поняття «документ» уживається для характеристики функцій різних адміністративних органів, визначення змісту і форми актів управління, а також реєстрації актів громадянського стану.

У кримінальному праві документ виступає як предмет вчинення конкретних злочинів.

Під документом у кримінальному процесі розуміють «спеціально створений з метою збереження інформації матеріальний об'єкт, який містить зафіксовані за допомогою письмових знаків, звуку, зображення тощо відомості, які можуть бути використані як доказ факту чи обставин, що встановлюються під час кримінального провадження» (Kryminalnyi protsesualnyi kodeks Ukrain, 2012, st. 99, ch. 1).

У трудовому праві з поняттям і видами документів пов'язане виникнення, припинення, здійснення трудових відносин: прийом на роботу, переведення, звільнення з роботи, трудовий стаж, відпустка, підвищення звання чи посади.

Поняття «документ» у цивільному праві пов'язане $з$ урегулюванням різноманітних видів цивільно-правових угод (договори, зобов'язання).

У криміналістиці, маючи специфічне значен- ня, документи виступають об'єктами криміналістичного дослідження щодо встановлення способу та часу виготовлення документа, наявності змін, які були внесені до нього, відновлення первинного змісту й інших обставин. Під документом розуміють «носії текстової або графічної інформації. При цьому має значення спосіб, за допомогою якого ця інформація фіксується на носії, систематизується, аналізується, передається або зберігається, а також методика, знання, предмети, часовий проміжок і матеріал, що служили для утворення конкретного документа» (Budziievskyi, 2011, s. 168; Tsarova, 2017, s. 30-32).

Слід наголосити, що значний внесок у процес розвитку поняття документа в криміналістичному розумінні зробили свого часу німецькі криміналісти в період 1875-1900 pp.

Так, за словами Меркель, документ являє собою «матеріальный, неодушевленный предметъ, который обладаетъ свойствомъ свидътельства (Zeugniss) въ пользу извбстныхъ обстоятельствъ»; Бурі стверджував, що документи - «неодушевленные, приготовленные человъческой рукой предметы, которые способны (geeignet sind) быть доказательствомъ извъстных обстоятельствъ»; Бродманн «подъ документомъ понимаетъ заявленіе (Erklärung), сдЂланное въ письменной формЂ»; Гейєр зазначає, що «подъ документомъ въ смысль уголовнаго кодекса сльдуетъ разумъть неодушевленный предметъ, который назначенъ и пригоденъ для доказательства фактовъ», Гуго Мейєр «подъ документомъ разумъетъ “такой предметъ, который благодаря властной волъ получаетъ назначеніе служить доказательствомъ извъстнаго факта"» (Zhizhilenko, 1900, s. 549-557).

У сучасній науці криміналістиці найбільш повне поняття документа сформулював відомий український учений і практик В. К. Лисиченко. На його думку, документ являє собою письмовий акт або спеціально виготовлений предмет, що закріплює знаками природних мовних систем письма або спеціальних наукових і технічних знакових систем конкретні волевиявлення та відомості функціонального характеру, практична значущість яких визначається нормами права (Lisichenko, 1972).

Завдяки науковим працям та обгрунтованим позиціям учених, криміналістів, практиків і фахівців у галузі криміналістичного документознавства поняття документа у криміналістичній площині набуло нових визначень.

Так, Р. С. Бєлкін документом вважає матеріальний об'єкт, у якому за допомогою знаків, символів і тому подібних елементів природної або штучної мови зафіксовані відомості про факти (Belkin, 2000, s. 68). 
3 погляду М. В. Салтевського «документ - це матеріально фіксована інформація поза пам'яттю людини та ЕОМ, що відображає своїм змістом юридично значущі відносини і факти, що породжують правові наслідки при використанні документів» (Saltevskyi, 2005, s. 211).

В. В. Бірюков документ розглядає як «складний матеріальний об'єкт, який містить інформацію, зафіксовану за допомогою штучної мови чи у формі графічних зображень безпосередньо людиною чи 3 використанням науково-технічних засобів, призначений для іiі передавання в просторі і часі» (Biriukov, Kovalenko, Biriukova, \& Kovalov, 2007, s. 20), a I. І. Попович як «письмовий акт або інший матеріальний предмет, який містить зафіксовану будь-яким способом фіксації інформацію про факти чи події, що мають значення для встановлення обставин у справі» (Popovych, 2011, s. 97).

Документ, на думку Т. В. Варфоломеєвої, В. Г. Гончаренка, В. І. Боярова, С. В. Гончаренка, В. О. Попелюшка, «являє собою матеріальний носій інформації, призначений для іiі передачі в часі і просторі» (Varfolomeieva, Honcharenko, Boiarov, Honcharenko, \& Popeliushko, 2011, s. 165).

$€$. С. Хижняк на підставі проведеного аналізу пропонує узагальнене поняття, розглядаючи документ як «матеріальний об’єкт, який містить інформацію, зафіксовану за допомогою штучної мови або у формі графічних зображень безпосередньо людиною або з використанням науково-технічних засобів, на підставі якої встановлюються обставини, що мають значення для кримінального провадження» (Khyzhniak, 2017, s. 208).

Підсумовуючи зазначене, варто наголосити, що документ у криміналістичному розумінні, з нашого погляду, - це складний матеріально-фіксований носій інформації, який містить у собі дані про певні обставини чи події, що відбувалися та мають значення для встановлення істини в досудовому розслідуванні або судовому розгляді справи.

3 огляду на те, що поняття документа широковживане в усіх сферах суспільної діяльності і в кожній галузі знань його розуміють відповідно до специфіки об'єкта, якому надається такий статус, можна констатувати його багатозначність, а отже, зважаючи на порушену нами проблематику, потребує визначення в розумінні криміналістичного документознавства та технічного дослідження документів, зокрема. Формування такого поняття надасть поштовх подальшому розвитку можливостей дослідження документа та започаткуванню нових науково-методичних підходів дослідження його складників.

Грунтуючись на аналізі ознак, властивостей, а також функцій і завдань документів як об'єктів дослідження, свого часу вчений-криміналіст
О. О. Жижиленко запропонував таку їх класифікацію:

за метою складання: засвідчують відому обставину (є доказом); набули силу доказів унаслідок певних обставин (лист, розписка тощо);

джерелом походження: походять від приватних осіб; від публічної влади;

змістом: засвідчують права, правовідносини та обставини, що мають правові наслідки; мають зміст неюридичного значення;

способом викладення: заяви; свідоцтва, засвідчення будь-чого;

значенням: процесуальні; документи поза процесом, у сфері життєдіяльності людини;

способом засвідчення відомої подї: виключають можливість доказування події іншими документами або засобами; не виключають можливості доказування в інший спосіб;

формою: мають наперед визначену форму; можуть складатися без дотримання встановлених вимог (Zhizhilenko, 1900, s. 542-543).

Запропонована система класифікації завдяки плідній праці вчених, практиків і фахівців у галузі криміналістики, загального та криміналістичного документознавства набула подальшого розвитку й удосконалення.

Сучасна класифікація документів, убачається, має будуватися на таких підставах:

за назвою: накази, розпорядження, договори, устави, довідки, записки, доручення та ін.;

походженням:

офіційні (службові), що видані установами, організаціями, підприємствами, тобто виходять від юридичних осіб (виконані в певній формі та мають встановлені реквізити);

неофіційні (особисті, приватні) - виходять від громадян. Такі документи можуть бути двох видів: складені за прийнятою або встановленою законом формою (заяви); складені у довільній формі (записки, листи тощо). При цьому в таких документах обов'язково зазначають прізвище, ім'я, по батькові заявника, його адресу, найменування установи й особи, якій спрямований документ. Документ скріплюється підписом укладача (автора);

cmуnенем доступу: нетаємні, $з$ обмеженим доступом, таємні, цілком таємні (Gavrilin, 2018, s. 26-30); мачіiі:

фізичною природою носія та фіксачії інфор-

документ на папері чи його замінниках (iнформація фіксується в письмовій чи графічній формі - рукописним, друкованим чи фотографічним способом);

документи на магнітних носіях (металеві феромагнітні диски, полімерні диски та плівки 3 нашаруванням феромагнетика), письмова та гра- 
фічна інформація, а також звук у цифровій або аналоговій формі, який фіксується електромагнітними сигналами з використанням спеціального обладнання; документи на немагнітних носіях (фото- та кіноплівки, кристали-флешкарти, алюмінієва фольга, нашарування на пластик тощо), письмова та графічна інформація, а також звук у цифровій чи аналоговій формі, який фіксується оптичними або електричними сигналами з використанням спеціального обладнання;

способом відображення інбормації: рукописні, виконані на друкарській машині, поліграфічним способом, з використанням засобів «малої поліграфії», з використанням спеціальних приладів, машин (ЕОМ, фотоапарата, відеокамери, а саме: фото-, кіно-, відео-, фонодокументи);

призначенням: засвідчують факти права; містять певні відомості;

строком зберігання: тимчасового; постійного; співвідношенням часу виготовлення документа і вчинення розслідуваного правопорушення:

виготовлено до вчинення;

під час вчинення;

після вчинення правопорушення, але під час провадження у справі;

проиесуальною значущістю:

документи - речові докази (слугували засобом скоєння злочину або зберегли на собі сліди злочинного впливу чи були об'єктом злочинного замаху);

документи - письмові докази (містять відомості про юридичні факти, зафіксовані в їхньому змісті, відображені в письмовій, графічній чи аудіовізуальній формі);

документи - зразки для порівняння (використовуються для порівняльного дослідження, щоб встановити об'єктивні дані стосовно сумнівного документа) (Shepitko (Red.), 2019, s. 220-221); юридичною чинністю:

справжній документ (містить відомості, що відповідають дійсності);

підроблений документ (містить завідомо неправдиві відомості та має ознаки підроблення: інтелектуального - внесення завідомо неправдивих відомостей до справжнього документа; матеріального - повного підроблення, коли повністю виготовляють підроблений за формою і змістом документ, і часткового, коли до реквізитів і змісту справжнього документа вносять часткові зміни способами, які залишають матеріальні сліди).

Інтелектуальне підроблення документа встановлюють під час слідчих дій та оперативно-розшукових заходів, проте за допомогою криміналістичного дослідження письма встановлюють автора, виконавця такого документа, факт підписання його конкретними особами.
Матеріальне підроблення (повне та часткове) встановлюють техніко-криміналістичними засобами, прийомами, методами, розробленими в межах складової сучасної галузі криміналістичної техніки - криміналістичного документознавства, а саме криміналістичного дослідження документів. До завдань такого дослідження належать: визначення способу виготовлення документа, ідентифікація матеріалу і знарядь письма; відновлення пошкоджених документів і записів у них; встановлення наявності і способу підроблення, визначення віку документа і записів у ньому; визначення послідовності штрихів, що перетинаються; прочитання тайнопису i розшифрування записів, виконаних умовними знаками або шрифтами; ідентифікація або діагностика способів і засобів виконання документів, печаток, штампів тощо (Volobuiev, Stepaniuk, \& Maliarova (Zah. red.), 2018, s. 217-218).

Зважаючи на позицію I. В. Царьової (Tsarova, 2017 , s. 17-18), можна зробити висновок, що об'єктом дослідження у техніко-криміналістичному дослідженні документів виступає винятково юридичний документ, який є письмовим актом, складеним згідно з правовими вимогами, містить правову інформацію (підтвердження прав, обов'язків або підтвердження юридичних фактів, подій чи дій, що тягнуть виникнення певних прав й обов'язків) і встановлює, розвиває, змінює чи припиняє певні правовідносини або фіксує юридично значущі факти й дії.

Ірунтуючись на аналогічній позиції, В. С. Сезонов пропонує розглядати документ у техніко-криміналістичному дослідженні як один із видів матеріальних носіїв зафіксованої в ньому інформації, що становить інтерес під час вирішення завдань (Sezonov, 2020, s. 134).

Найчастіше об’єктом дослідження виступає типовий документ, тобто документ, що відображає однорідні питання, укладають його за визначеними зразками; нормативний чи розпорядчий документ, що визначає порядок роботи установ або окремих аспектів їхньої діяльності, $є$ зразком для укладання однойменних документів установами, зважаючи на специфіку їхньої діяльності; документ, створений в установі під час виконання функцій, властивих більшості установ, незалежно від їх відомчої належності (Tsarova, 2017, s. 167).

При цьому в документі як об'єкті криміналістичного дослідження виокремлюють дві складові: бланк і реквізити.

Бланк - надрукована на папері чи іншому носієві інформація встановленого зразка (Shemshuchenko (Vidp. red.), 1998, s. 251) та уніфікована форма певного документа в електронному вигляді (електронний бланк), що заповнюється 
конкретними даними (необхідною інформацією) у спеціально відведених для цього місцях, 3 подальшим друком на матеріальному носії.

Кожний юридичний документ повинен містити свої реквізити (від лат. requisitum - потрібне, необхідне), тобто «сукупність обов'язкових даних чи відомостей, встановлених нормативно-правовими актами або чинними правилами діловодства, без яких він не може бути підставою для обліку, здійснення певних операцій і не має юридичної сили». При цьому самі реквізити поділяються на постійні - наносяться за встановленим зразком під час виготовлення бланків документів та змінні - наносяться на бланк документа в процесі його заповнення (Shemshuchenko (Vidp. red.), 2003, s. 279).

Склад і розміщення реквізитів на бланках юридичних документів визначається Державним стандартом (ДСТУ) 4163-2003 «Уніфікована система організаційно-розпорядчої документації. Вимоги до оформлювання документів».

Готуючи та оформлюючи документи, використовують такі реквізити: зображення Державного Герба України, герба Автономної Республіки Крим; емблеми організації або товарного знака (знака обслуговування); нагород; код організації; код форми документа; назва організації вищого рівня; назва організації; назва структурного підрозділу організації; довідкові дані про організацію; назва виду документа; дата документа; реєстраційний індекс документа; посилання на реєстраційний індекс і дату документа, на який дають відповідь; місце складення або видання документа; гриф обмеження доступу до документа; адресат; гриф затвердження документа; резолюція; заголовок до тексту документа; відмітка про контроль; текст документа; відмітка про наявність додатків; підпис; гриф погодження документа; візи документа; відбиток печатки; відмітка про засвідчення копії; прізвище виконавця і номер його телефону; відмітка про виконання документа і направлення його до справи; відмітка про наявність документа в електронній формі; відмітка про надійдення документа до організації; запис про державну реєстрацію (Derzhavna unifikovana systema dokumentatsii, 2003, pidp. 4.1).

При цьому слід зауважити, що під час дослідження із застосуванням загальних чи специфічних методів кожний із зазначених реквізитів, окремо або в сукупності, $є$ джерелом інформації, на підставі чого експерт вирішує питання про давність виготовлення документа.

Тож, грунтуючись на науковому доробку не одного покоління фахівців з юриспруденції, криміналістики та інших галузей життєдіяльності людини, можна сформувати окрему авторську дефініцію поняття документа в галузі криміналістичного документознавства, зважаючи на специфічні вимоги до документа як об’єкта дослідження у криміналістичному дослідженні документів, у тому числі при визначенні давності його виготовлення.

Так, убачається, документом слід вважати матеріальний носій юридично значущої інформації, оформлений згідно з вимогами на папері або його замінниках, у придатному для дослідження стані, на якому залишилися ознаки технології виготовлення, певних обставин чи подій, які відбувалися у певний проміжок часу, різноманітних змін, внесених до нього випадково або навмисно, що можуть бути виявлені експертом і які матимуть значення для встановлення істини у справі.

\section{Наукова новизна}

Уточнено поняття документа у криміналістичній площині. Надано авторське поняття документа як об'єкта дослідження в галузі криміналістичного документознавства, зокрема технічної експертизи документів, з метою визначення давності його виготовлення. Сформовано підгрунтя для створення нової експертної спеціальності - дослідження давності виготовлення документа.

\section{Висновки}

1. Проаналізовано етапи створення та розвитку документа як матеріального носія інформації у просторі і часі, генезис загального та спеціального поняття документа, зокрема й у криміналістичному розумінні. Визначено критерії формування поняття документа як об'єкта дослідження в галузі криміналістичного документознавства і технічної експертизи документів.

2. Запропоновано такий уточнений варіант визначення поняття документа у криміналістичному розумінні: документ - це складний матеріально-фіксований носій інформації, який містить у собі дані про певні обставини чи події, що відбувалися та мають значення для встановлення істини в досудовому розслідуванні або судовому розгляді справи.

3. Грунтуючись на узагальненні наукової думки з порушеного питання, сформовано поняття документа як об’єкта дослідження в галузі криміналістичного документознавства, зокрема технічної експертизи документів, з метою визначення давності його виготовлення. При цьому, з нашого погляду, документом слід вважати матеріальний носій юридично значущої інформації, оформлений згідно з вимогами на папері або його замінниках, у придатному для дослідження стані, на якому залишилися ознаки технології виготовлення, пев- 
них обставин чи подій, які відбувалися у певний проміжок часу, різноманітних змін, внесених до нього випадково або навмисно, що можуть бути виявлені експертом і які матимуть значення для встановлення істини у справі.
4. Надано пропозиції з удосконалення наявних і формування нових науково-методичних підходів, що становлять підгрунтя для створення нової експертної спеціальності - дослідження давності виготовлення документа.

\section{References}

Antoniuk, A. B., Zakharkiv, T. I., \& Franchuk, M. I. (2020). Zahalnoteoretychnyi pidkhid do doslidzhennia pidroblenykh tekstiv i dokumentiv u kryminalistychnii ekspertyzi. Pravovi novely, 10, 269-274 [in Ukrainian]. DOI: https://doi.org/10.32847/ln.2020.10.37 .

Belkin, R. S. (2000). Kriminalisticheskaia entciklopediia (2-e izd., dop.). M.: Megatron XXI. 334 s. [in Russian].

Bezdrabko, V. V. (2017). Istorychne dokumentoznavstvo v Ukraini: suchasnyi stan i perspektyvy. Bibliotekoznavstvo. Dokumentoznavstvo. Informolohiia, 4, 4-23 [in Ukrainian]. DOI: https://doi.org/10.32461/2409-9805.4.2017.150414.

Bilodid, I. K. (Holova redkol.). (1971). Slovnyk ukrainskoi movy (V 11 t. T. 2: H-Zh. 550 c.). Kyiv: Naukova dumka [in Ukrainian].

Biriukov, V. V., Kovalenko, V. V., Biriukova, T. P., \& Kovalov, K. M. (2007). Kryminalistychne dokumentoznavstvo: prakt. posib. (za zah. red. V. V. Biriukova). Kyiv: Vyd. Palyvoda A. V. 332 s. [in Ukrainian].

Bogacz, B., \& Mara, H. (2020). Period Classification of 3D Cuneiform Tablets with Geometric Neural Networks. 2020 17th International Conference on Frontiers in Handwriting Recognition (ICFHR), 246-251. DOI: 10.1109/ICFHR2020.2020.00053.

Budziievskyi, M. Yu. (2011). Do dyskusii pro poniattia elektronnoho dokumenta. Derzhava ta rehiony. Seriia: Pravo, 1, 167-170 [in Ukrainian].

Busel, V. T. (Uklad. i Holov. red.). (2005). Velykyi tlumachnyi slovnyk suchasnoi ukrainskoi movy: 250 000. Kyiv; Irpin: Perun. VIII, 1728 s. [in Ukrainian].

Cherniatynska, Yu. H. (2017). Teoretyko-metodolohichni zasady ekspertyzy tsinnosti dokumentiv v elektronnii formi. Naukovi pratsi istorychnoho fakultetu Zaporizkoho natsionalnoho universytetu, 49, 251-254 [in Ukrainian]. DOI: https://doi.org/10.26661/swfh-2017-49-047.

Dencker, T., Klinkisch, P., Maul, S. M., \& Ommer, B. (2020). Deep learning of cuneiform sign detection with weak supervision using transliteration alignment. PLoS ONE, 15. DOI: 10.1371/journal.pone.0243039.

Derzhavna unifikovana systema dokumentatsii. Unifikovana systema orhanizatsiino-rozporiadchoi dokumentatsii. Vymohy do oformliuvannia dokumentiv. (2003). DSTU 4163-2003. Chyn. vid 2003-09-01. Kyiv: Derzhspozhyvstandart Ukrainy. 26 s. [in Ukrainian].

Dilovodstvo y arkhivna sprava. Terminy ta vyznachennia poniat. (2005). DSTU 2732:2004. Chyn. vid 2005-07-01. Kyiv: Derzhspozhyvstandart. 32 s. [in Ukrainian].

Garain, U., \& Halder, B. (2020). Even big data is not enough: need for a novel reference modelling for forensic document authentication. IJDAR, 23, 1-11. DOI: https://doi.org/10.1007/s10032-019-00345-w.

Gavrilin, S. A. (2018). K voprosu o kriminalisticheskoi klassifikatcii dokumentov. Vestnik Moskovskogo universiteta MVD Rossii, 4, 26-30 [in Russian].

Golovanov, N. M., Kulikova, A. A., Shmalij, O. V., Tychinin, S. V., \& Hlebnikov, A. D. (2018). Legislative Approaches to the Electronic Document Definition and its Evidentiary Value in the CIS Countries. The Scientific Explorer. Helix, 8 (4), 3503-3507.

DOI: $10.29042 / 2018-3503-3507$

Informatsiia ta dokumentatsiia. Bazovi poniattia. Terminy ta vyznachennia. (1994). DSTU 2392-94. Chyn. vid 1995-01-01. Kyiv: Derzhstandart Ukrainy. 53 s. Utratyv chynnist [in Ukrainian].

Kelly, J. S., \& Angel, M. (Eds.). (2020). Forensic Document Examination in the 21st Century (1st ed.). CRC Press. DOI: https://doi.org/10.4324/9780367853587.

Khyzhniak, Ye. S. (2017). Taktychni pryiomy provedennia slidchoho ohliadu dokumentiv. Aktualni problemy vitchyznianoi yurysprudentsii, 3, 207-211 [in Ukrainian].

Komova, M. (2019). Classification scheme as a reflection of the social and communicative nature of document phenomenon. Bibliotekoznavstvo. Dokumentoznavstvo. Informolohiia, 3, 27-35. DOI: https://doi.org/10.32461/2409-9805.3.2019.187917.

Kryminalnyi protsesualnyi kodeks Ukrainy: Zakon Ukrainy № 4651-VI. (2012). Uziato z https://zakon.rada.gov.ua/laws/ show/4651-17\#n1191 [in Ukrainian].

Kuleshov, S. H. (2012). Zahalne dokumentoznavstvo: navch. posib. Kyiv: Kyievo-Mohylianska akademiia. 123 s. [in Ukrainian].

Kushnarenko, N. N. (2006). Dokumentovedenie: uchebnik (7-e izd., ster.). Kiev: Znannia. 459 s. [in Russian].

Lazarev, V. S. (2020). Rasshirenie znacheniia termina «dokument» kak faktor vozmozhnogo pereosmysleniia obektov bibliometrii, naukometrii I informetrii. 2. Starye opredeleniia obektov «metrii» v kontekste novogo opredeleniia termina 
«dokument». Nauka i nauchnaia informatciia, 3 (4), 261-277 [in Russian].

DOI: https://doi.org/10.24108/2658-3143-2020-3-4-226-242.

Lisichenko, V. K. (1972). Iuridicheskoe poniatie dokumenta i ego znachenie. Kriminalisticheskaia i sudebnaia ekspertiza, 9 , 179-188 [in Russian].

Lombardi, F., \& Marinai, S. (2020). Deep Learning for Historical Document Analysis and Recognition - A Survey. Journal of Imaging, 6 (10), 110.

DOI: https://doi.org/10.3390/jimaging6100110.

Melnychuk, O. S. (Hol. red.). (1985). Etymolohichnyi slovnyk ukrainskoi movy. (U 7 t. T. 2: D-Koptsi. 572 s.). Kyiv: Naukova dumka [in Ukrainian].

Mysak, M. (2016). Rozvytok paperovoho vyrobnytstva: kulturno-istorychnyi aspekt. Visnyk Lvivskoi natsionalnoi akademii mystetstv, 28, 239-251 [in Ukrainian]. DOI: https://doi.org/10.5281/zenodo.51668.

Otle, P. (1924). Rukovodstvo k administrirovaniiu. Perevod s frantc. M.: NKRKI. 84 s. [in Russian].

Otlet, P. (1934). Traite de Documentation: Le Livre sur le Livre: Theori et pratique. Bruxelles. Tiré de http://traite.czam.de/ en/latest/otlet_traite_1934_FR.html.

Palekha, Yu. I., \& Lemish, N. O. (2011). Istoriia dilovodstva (Dokumentoznavchyi aspekt): navch. posib. dlia vyshch. navch. zakl. Kyiv: Lira-K. 323, [5] s. [in Ukrainian].

Popovych, I. I. (2011). Pliuralizm dumok shchodo poniattia dokumenta u kryminalistytsi. Naukovyi visnyk Uzhhorodskoho universytetu. Seriia: Pravo, 15, 95-98 [in Ukrainian].

Pro informatsiiu: Zakon Ukrainy № 2657-XII. (1992). Uziato z https://zakon.rada.gov.ua/laws/show/2657-12\#Text [in Ukrainian].

Pustovit, L. O., Skopnenko, O. I., Siuta, H. M., \& Tsymbaliuk, T. V. (Uklad.). (2000). Slovnyk inshomovnykh sliv: 23000 sliv ta terminolohichnykh slovospoluchen. Kyiv: Dovira: UNVTs «Ridna mova». 1017 s. [in Ukrainian].

Saltevskyi, M. V. (2005). Kryminalistyka. Kyiv: Kondor. 588 s. [in Ukrainian].

Sánchez, J., Romero, V., Toselli, A., Villegas, M., \& Vidal, E. (2019). A set of benchmarks for Handwritten Text Recognition on historical documents. Pattern Recognit, 94, 122-134.

DOI: 10.1016/J.PATCOG.2019.05.025.

Sakovskyi, A. (2020). Operatyvno-rozshukove dokumentuvannia yak poshukovo-piznavalnyi protses i skladnyk operatyvno-rozshukovoi diialnosti. Pidpryiemnytstvo, hospodarstvo i pravo, 7, 371-377 [in Ukrainian]. DOI: https://doi.org/10.32849/2663-5313/2020.7.63.

Sezonov, V. S. (2020) Henezys kryminalistychnoho doslidzhennia dokumentiv yak haluzi kryminalistychnoi tekhniky [The genesis of forensic research of documents as the branch of forensic technology]. Pravo i Bezpeka, 2 (77), 133-140 [in Ukrainian].

DOI: https://doi.org/10.32631/pb.2020.2.18.

Shemshuchenko, Yu. S. (Vidp. red.). (1998). Yurydychna entsyklopediia. (U 6 t. T 1: A-H). Kyiv: Ukr. entsykl. 672 s. [in Ukrainian].

Shemshuchenko, Yu. S. (Vidp. red.). (2003). Yurydychna entsyklopediia. (U 6 t. T. 5: P-S). Kyiv: Ukr. entsykl. 736 s. [in Ukrainian].

Shepitko, V. Yu. (Red.). (2019). Kryminalistyka: pidruchnyk. (U 2 t. T. 1). Kharkiv: Pravo. 456 s. [in Ukrainian].

Shvetsova-Vodka, H. M. (1998). Typolohiia dokumenta: navch. posib. dlia studentiv in-tiv kultury. Kyiv: Kn. palata Ukrainy. 78 s. [in Ukrainian].

Stratonov, S. Yu. (2020). Obiekty ekspertyzy vstanovlennia davnosti dokumenta. Pravo i suspilstvo, 2 (3), 152-158 [in Ukrainian].

DOI: https://doi.org/10.32842/2078-3736/2020.2-3.24.

Tsarova, I. V. (2017). Yurydychne dokumentoznavstvo: navch. posib. Dnipro: Dnipropetr. derzh. un-t vnutr. sprav. 172 s. [in Ukrainian].

van Erp, M., Vuurpijt, L., Franke, K., \& Schomaker, L. (2018). The Wanda Measurement Tool for Forensic Document Examination. Journal of Forensic Document Examination, 28, 5-14. DOI: https://doi.org/10.31974/jfde28-5-14.

Varfolomeieva, T. V., Honcharenko, V. H., Boiarov, V. I., Honcharenko, S. V., \& Popeliushko, V. O. (2011). Kryminalistyka. Akademichnyi kurs: pidruchnyk. Kyiv: Yurinkom Inter. 504 s. [in Ukrainian].

Volobuiev, A. F., Stepaniuk, R. L., \& Maliarova, V. O. (Zah. red.). (2018). Kryminalistyka: pidruchnyk. (U 2 t. T. 1). Kharkiv: Kharkiv. nats. un-t vnutr. sprav. 384 s. [in Ukrainian].

Vydannia. Osnovni vydy. Terminy ta vyznachennia. (1995). DSTU 3017-95. Chyn. vid 1996-01-01. Kyiv: Derzhstandart Ukrainy. 46 s. Utratyv chynnist [in Ukrainian].

Yudina, I. V. (2018). Aktualni pytannia kryminalistychnoho doslidzhennia dokumentiv zi zminenym pervynnym zmistom. Kryminalistychnyi visnyk, 2 (30), 78-91 [in Ukrainian]. DOI: https://doi.org/10.37025/1992-4437/2018-30-2-78.

Zhizhilenko, A. A. (1900). Podlog dokumentov: Istoriko-dogmaticheskoe izsledovanie. S.-Peterburg: Nevskaia tipografiia. 746 s. [in Russian]. 


\section{Список використаних джерел}

Антонюк, А. Б., Захарків, Т. І., \& Франчук, М. І. (2020). Загальнотеоретичний підхід до дослідження підроблених текстів і документів у криміналістичній експертизі. Правові новели, 10, 269-274. DOI: https://doi.org/10.32847/ln.2020.10.37.

Белкин, Р. С. (2000). Криминалистическая энииклопедия (2-е изд., доп.). М.: Мегатрон XXI. 334 с.

Бездрабко, В. В. (2017). Історичне документознавство в Україні: сучасний стан і перспективи. Бібліотекознавство. Документознавство. Інформологія, 4, 4-23.

DOI: https://doi.org/10.32461/2409-9805.4.2017.150414.

Білодід, І. К. (Голова редкол.). (1971). Словник української мови (В 11 т. Т. 2: Г-Ж. 550 с.). Київ: Наукова думка.

Бірюков, В. В., Коваленко, В. В., Бірюкова, Т. П., \& Ковальов, К. М. (2007). Криміналістичне документознавство: практ. посіб. (за заг. ред. В. В. Бірюкова). Київ: Вид. Паливода А. В. 332 с.

Bogacz, B., \& Mara, H. (2020). Period Classification of 3D Cuneiform Tablets with Geometric Neural Networks. 2020 17th International Conference on Frontiers in Handwriting Recognition (ICFHR), 246-251. DOI: 10.1109/ICFHR2020.2020.00053.

Будзієвський, М. Ю. (2011). До дискусії про поняття електронного документа. Держава та регіони. Серія: Право, 1, 167-170.

Бусел, В. Т. (Уклад. і Голов. ред.). (2005). Великий тлумачний словник сучасної української мови: 250 000. Київ; Ірпінь: Перун. VIII, 1728 с.

Чернятинська, Ю. Г. (2017). Теоретико-методологічні засади експертизи цінності документів в електронній формі. Наукові праці історичного факультету Запорізького національного університету, 49, 251-254. DOI: https://doi.org/10.26661/swfh-2017-49-047.

Dencker, T., Klinkisch, P., Maul, S. M., \& Ommer, B. (2020). Deep learning of cuneiform sign detection with weak supervision using transliteration alignment. PLoS ONE, 15.

DOI: 10.1371/journal.pone.0243039.

Державна уніфікована система документації. Уніфікована система організаційно-розпорядчої документації. Вимоги до оформлювання документів. (2003). ДСТУ 4163-2003. Чин. від 2003-09-01. Київ: Держспоживстандарт України. 26 с.

Діловодство й архівна справа. Терміни та визначення понять. (2005). ДСТУ 2732:2004. Чин. від 2005-07-01. Київ: Держспоживстандарт. 32 с.

Garain, U., \& Halder, B. (2020). Even big data is not enough: need for a novel reference modelling for forensic document authentication. IJDAR, 23, 1-11. DOI: https://doi.org/10.1007/s10032-019-00345-w.

Гаврилин, С. А. (2018). К вопросу о криминалистической классификации документов. Вестник Московского университета МВД России, 4, 26-30.

Golovanov, N. M., Kulikova, A. A., Shmalij, O. V., Tychinin, S. V., \& Hlebnikov, A. D. (2018). Legislative Approaches to the Electronic Document Definition and its Evidentiary Value in the CIS Countries. The Scientific Explorer. Helix, 8 (4), 3503-3507.

DOI: $10.29042 / 2018-3503-3507$.

Інформація та документація. Базові поняття. Терміни та визначення. (1994). ДСТУ 2392-94. Чин. від 1995-01-01. Київ: Держстандарт України. 53 с. Утратив чинність.

Kelly, J. S., \& Angel, M. (Eds.). (2020). Forensic Document Examination in the 21st Century (1st ed.). CRC Press. DOI: https://doi.org/10.4324/9780367853587.

Хижняк, Є. С. (2017). Тактичні прийоми проведення слідчого огляду документів. Актуальні проблеми вітчизняноі юриспрудениії, 3, 207-211.

Komova, M. (2019). Classification scheme as a reflection of the social and communicative nature of document phenomenon. Бібліотекознавство. Документознавство. Інформологія, 3, 27-35. DOI: https://doi.org/10.32461/2409-9805.3.2019.187917.

Кримінальний процесуальний кодекс України: Закон України № 4651-VI. (2012). Узято з https://zakon.rada.gov.ua/ laws/show/4651-17\#n1191.

Кулешов, С. Г. (2012). Загальне документознавство: навч. посіб. Київ: Києво-Могилянська академія. 123 с.

Кушнаренко, Н. Н. (2006). Документоведение: учебник (7-е изд., стер.). Киев: Знання. 459 с.

Лазарев, В. С. (2020). Расширение значения термина «документ» как фактор возможного переосмысления объектов библиометрии, наукометрии и информетрии. 2. Старые определения объектов «метрий» в контексте нового определения термина «документ». Наука и научная информация, 3 (4), 261-277.

DOI: https://doi.org/10.24108/2658-3143-2020-3-4-226-242.

Лисиченко, В. К. (1972). Юридическое понятие документа и его значение. Криминалистическая и судебная експертиза, 9, 179-188.

Lombardi, F., \& Marinai, S. (2020). Deep Learning for Historical Document Analysis and Recognition - A Survey. Journal of Imaging, 6 (10), 110.

DOI: https://doi.org/10.3390/jimaging6100110. 
Мельничук, О. С. (Гол. ред.). (1985). Етимологічний словник української мови. (У 7 т. Т. 2: Д-Копці. 572 с.). Київ: Наукова думка.

Мисак, М. (2016). Розвиток паперового виробництва: культурно-історичний аспект. Вісник Львівської національної академї мистецтв, 28, 239-251.

DOI: https://doi.org/10.5281/zenodo.51668.

Отле, П. (1924). Руководство к администрированию. Перевод с франц. М.: НКРКИ. 84 с.

Otlet, P. (1934). Traite de Documentation: Le Livre sur le Livre: Theori et pratique. Bruxelles. Tiré de http://traite.czam.de/ en/latest/otlet_traite_1934_FR.html.

Палеха, Ю. І., \& Леміш, Н. О. (2011). Історія діловодства (Документознавчий аспект): навч. посіб. для вищ. навч. закл. Київ: Ліра-К. 323, [5] с.

Попович, І. І. (2011). Плюралізм думок щодо поняття документа у криміналістиці. Науковий вісник Ужгородського університету. Серія: Право, 15, 95-98.

Про інформацію: Закон України № 2657-XII. (1992). Узято з https://zakon.rada.gov.ua/laws/show/2657-12\#Text.

Пустовіт, Л. О., Скопненко, О. І., Сюта, Г. М., \& Цимбалюк, Т. В. (Уклад.). (2000). Словник іншомовних слів: 23000 слів та термінологічних словосполучень. Київ: Довіра: УНВЦ «Рідна мова». 1017 с.

Салтевський, М. В. (2005). Криміналістика. Київ: Кондор. 588 с.

Sánchez, J., Romero, V., Toselli, A., Villegas, M., \& Vidal, E. (2019). A set of benchmarks for Handwritten Text Recognition on historical documents. Pattern Recognit, 94, 122-134. DOI: 10.1016/J.PATCOG.2019.05.025.

Саковський, А. (2020). Оперативно-розшукове документування як пошуково-пізнавальний процес і складник оперативно-розшукової діяльності. Підприємництво, господарство і право, 7, 371-377. DOI: https://doi.org/10.32849/2663-5313/2020.7.63.

Сезонов, В. С. (2020). Генезис криміналістичного дослідження документів як галузі криміналістичної техніки [Тһе genesis of forensic research of documents as the branch of forensic technology]. Право і Безпека, 2 (77), $133-140$. DOI: https://doi.org/10.32631/pb.2020.2.18.

Шемшученко, Ю. С. (Відп. ред.). (1998). Юридична енциклопедія. (У 6 т. Т. 1: А - Г). Київ: Укр. енцикл. 672 с.

Шемшученко, Ю. С. (Відп. ред.). (2003). Юридична енциклопедія. (У 6 т. Т. 5: П - С). Київ: Укр. енцикл. 736 с.

Шепітько, В. Ю. (Ред.). (2019). Криміналістика: підручник. (У 2 т. Т. 1). Харків: Право. 456 с.

Швецова-Водка, Г. М. (1998). Типологія документа: навч. посіб. для студентів ін-тів культури. Київ: Кн. палата України. $78 \mathrm{c.}$

Стратонов, С. Ю. (2020). Об’єкти експертизи встановлення давності документа. Право і суспільство, 2 (3), $152-158$. DOI: https://doi.org/10.32842/2078-3736/2020.2-3.24.

Царьова, I. В. (2017). Юридичне документознавство: навч. посіб. Дніпро: Дніпропетр. держ. ун-т внутр. справ. $172 \mathrm{c}$.

van Erp, M., Vuurpijt, L., Franke, K., \& Schomaker, L. (2018). The Wanda Measurement Tool for Forensic Document Examination. Journal of Forensic Document Examination, 28, 5-14. DOI: https://doi.org/10.31974/jfde28-5-14.

Варфоломеєва, Т. В., Гончаренко, В. Г., Бояров, В. І., Гончаренко, С. В., \& Попелюшко, В. О. (2011). Криміналістика. Академічний курс: підручник. Київ: Юрінком Інтер. 504 с.

Волобуєв, А. Ф., Степанюк, Р. Л., \& Малярова, В. О. (Заг. ред.). (2018). Криміналістика: підручник. (У 2 т. Т. 1). Харків: Харків. нац. ун-т внутр. справ. 384 с.

Видання. Основні види. Терміни та визначення. (1995). ДСТУ 3017-95. Чин. від 1996-01-01. Київ: Держстандарт України. 46 с. Утратив чинність.

Юдіна, І. В. (2018). Актуальні питання криміналістичного дослідження документів зі зміненим первинним змістом. Криміналістичний вісник, 2 (30), 78-91. DOI: https://doi.org/10.37025/1992-4437/2018-30-2-78.

Жижиленко, А. А. (1900). Подлогъ документовъ: Историко-догматическое изследованіе. С.-Петербургъ: Невская типография. 746 с. 
K. Kovalov, Deputy Director,

State Scientific Research Forensic Centre,

MIA of Ukraine, Kyiv, Ukraine

ORCID: https://orcid.org/0000-0003-1964-9283

\title{
GENESIS OF THE DOCUMENT AS A PRINCIPLE OF CRIMINAL SCIENTIFIC DOCUMENTATION AND THE OBJECT OF RESEARCH IN THE TECHNICAL EXAMINATION OF THE ANTIQUITY OF THE DOCUMENT
}

\begin{abstract}
The purpose of the article is to define the document as the basis of forensic documentation and the object of study in the technical examination of the antiquity of the document through the prism of its formation and development, which will improve existing and form new scientific and methodological approaches as a basis for creating a new expert specialty - research of prescription of production of the document. Methodology. The reliability of the obtained results and conclusions is ensured by the use of a set of general scientific research methods, including analysis, synthesis, induction, analogy, deduction, etc. In addition, for practical implementation, such forms of knowledge as concepts, laws, hypotheses, theories are used, which allow further application of them, receiving scientific testing. Scientific novelty. The concept of the document in the forensic sphere is specified. The author's concept of the document as an object of research in the field of forensic document science, in particular technical examination of documents, in order to determine its antiquity. The basis for the creation of a new expert specialty - the study of the statute of limitations for the production of the document. Conclusions. The stages of creation and development of the document as a material carrier of information in space and time, the genesis of the general and special concept of the document, in particular in the forensic sense, are analyzed. The criteria for forming the concept of a document as an object of research in the field of forensic document science and technical examination of documents are defined. Suggestions for improving existing and forming new scientific and methodological approaches are provided, which form the basis for the creation of a new expert specialty - the study of the statute of antiquity of the document.
\end{abstract}

Keywords: document; genesis of the concept of the document; forensic document science; technical examination of documents; determining the antiquity the document.

\author{
К. Н. Ковалев, заместитель директора, \\ Государственный научно-исследовательский \\ экспертно-криминалистический центр \\ МВД Украинь, г. Киев \\ ORCID: https://orcid.org/0000-0003-1964-9283
}

\section{ГЕНЕЗИС ДОКУМЕНТА КАК ОСНОВЫ КРИМИНАЛИСТИЧЕСКОГО ДОКУМЕНТОВЕДЕНИЯ И ОБЪЕКТА ИССЛЕДОВАНИЯ В ТЕХНИЧЕСКОЙ ЭКСПЕРТИЗЕ ДАВНОСТИ ДОКУМЕНТА}

\begin{abstract}
Цель статьи заключается в определении документа как основы криминалистического документоведения и объекта исследования в технической экспертизе давности документа сквозь призму его становления и развития, что позволит усовершенствовать имеющиеся и сформировать новые научно-методические подходы как фундамент для создания новой экспертной специальности - исследование давности изготовления документа. Методология. Достоверность полученных результатов и выводов обеспечена использованием комплекса общенаучных методов исследования, среди них анализ, синтез, индукция, аналогия, дедукция и т. п. Кроме того, для практической реализации использованы следующие формы знания: понятия, законы, гипотезы, теории, позволяющие в дальнейшем применять их, получая научную апробацию. Научная новизна. Уточнено понятие документа с криминалистической точки зрения. Предложено авторское понятие документа как объекта исследования в области криминалистического документоведения, в частности технической экспертизы документов, с целью определения давности его изготовления. Сформирован базис для создания новой экспертной специальности - исследование давности изготовления документа. Bbıоды. Проанализированы этапы создания и развития документа как материального носителя информации в пространстве и времени, генезис общего и специального понятия документа, в частности в криминалистическом смысле. Определены критерии формирования понятия документа как объекта исследования в области криминалистического документоведения и технической экспертизы документов. Изложена собственная позиция касательно совершенствования существующих и формирования новых научно-методических подходов, составляющих основу для создания новой экспертной специальности - исследование давности изготовления документа.
\end{abstract}

Ключевые слова: документ; генезис понятия документа; криминалистическое документоведение; техническая экспертиза документов; определение давности изготовления документа. 